\title{
Bioactive Compounds and Antihypertensive Activity of Extracts of Hibiscus sabdariffa $\mathrm{L}$
}

\section{Compuestos bioactivos y actividad antihipertensiva de extractos de Hibiscus sabdariffa L.}

\author{
Perla Yuridia Montes-Rubio ${ }^{a}$, Héctor Enrique Fabela-Illescas ${ }^{b}$
}

Received: 28/08/2018, Accepted: 07/12/2018, Published: 05/01/2019

\begin{abstract}
:
Introduction: systemic arterial hypertension (SAH) is the main risk factor for the developing of cardiovascular disease, which the leading cause of death worldwide. One of the best ways to control blood pressure (BP) levels is the combination of lifestyle changes and drug therapy. However, pharmacotherapy is expensive and produces adverse reactions. Thus, it is necessary to find cheap, safe and effective alternative treatments. Hibiscus sabdariffa L. (HS) is a plant that is traditionally used in some countries to treat SAH, which has given rise to various investigations to determine their compounds and their antihypertensive activity. Aim: the present article aims at reviewing the reports that support the antihypertensive activity of extracts from HS in animal and human models Conclusions: the information collected from scientific literature suggests that HS extracts have antihypertensive effects in animals and humans, especially in early stages; however, more studies in advanced stages of hypertension are needed.
\end{abstract}

Keywords:

systemic arterial hypertension, extracts of Hibiscus sabdariffa, antihypertensive, treatment

\section{Resumen:}

Introducción: la hipertensión arterial sistémica (HAS) es el principal factor de riesgo para desarrollar enfermedades cardiovasculares, que a su vez son la principal causa de muerte en el mundo. La mejor forma de controlar los niveles de presión arterial (PA) es la combinación de cambios en el estilo de vida y el tratamiento farmacológico, sin embargo, este último es costoso y en la mayoría de los pacientes ocasiona gastos de bolsillo, además de efectos secundarios adversos. Esto ha generado la necesidad de buscar tratamientos eficaces, seguros y accesibles, tanto económica como físicamente. Hibiscus sabdariffa L. (HS) es una planta que se usa tradicionalmente en algunos países para tratar la HAS, lo que ha dado origen a diversas investigaciones para determinar sus compuestos y su actividad antihipertensiva. Objetivo: el presente artículo tuvo como finalidad hacer una revisión de la evidencia científica del tratamiento antihipertensivo de extractos de HS en modelos animales y en pacientes humanos, así como revisar los compuestos de la planta. Conclusiones: la información recopilada de la literatura científica sugiere que los extractos de HS tienen efectos antihipertensivos en animales y humanos, especialmente en etapas tempranas de HAS, sin embargo, se necesitan más estudios en etapas avanzadas de la enfermedad.

\section{Palabras Clave:}

hipertensión arterial sistémica, extractos de Hibiscus sabdariffa, antihipertensiva, tratamiento

\section{INTRODUCTION}

Systemic arterial hypertension (SAH) is the main risk factor for the developing of cardiovascular disease, especially ischemic heart disease and cerebrovascular disease. Around the world, cardiovascular diseases are responsible for approximately 17 million deaths per year, representing almost one third of the whole total, only

\footnotetext{
${ }^{a}$ Corresponding author: Agency for Rural Development GACOCA S.C. PESA/FAO/SAGARPA. Pachuca, Hidalgo. Mexico, Email: pymr143c@hotmail.com.

${ }^{\mathrm{b}}$ Ministry of Health of the State of Hidalgo, Local Coordination of Operative Staff ENPCSOD First Level of Attention. Pachuca, Hidalgo. 
complications derived from SAH cause 9.4 million deaths per year. Unfortunately, about $40 \%$ of the population over 25 years old has been diagnosed with SAH around the world. ${ }^{1,2}$

According to the National Survey on Health and Nutrition Half Way of Mexico (ENSANUT MC) ${ }^{3}$, the current prevalence of $\mathrm{SAH}$ is around $25.5 \%$, that is, 1 out of every 4 Mexicans; however, $40.0 \%$ of the population do not know they have this disease. Within the patients with a previous diagnosis, only $58.7 \%$ had controlled blood pressure (BP) levels and $79.3 \%$ were in pharmacological treatment, representing, in most cases, an out-of-pocket expense, since pharmacies of the health care services units do not always have the drugs and the medication must be permanent. ${ }^{4}$

There is also evidence that identifies polypharmacy and the adverse effects of medications as some factors for non-adherence to pharmacological treatment. ${ }^{5,6}$

For these reasons, the antihypertensive effects of natural products such as garlic (Allium sativum L.) ${ }^{7}$, hawthorn (Crataegus monogyna Jacq. $)^{8}$, passion fruit (Passiflora edulis) ${ }^{9}$ and olive (Olea europea L.) $)^{10}$ have been investigated; however, Hibiscus sabdariffa L. (HS) is a plant that is usually consumed which makes it culturally more accepted, besides it is affordable and easy to get, becoming a better option for patients with $\mathrm{SAH}$.

\section{HIBISCUS SABDARIFFA L.}

HS, known as jamaica or flor de jamaica [flower of jamaica] in Mexico, belongs to the family Malvace (Table 1). It is a native plant of Africa but is cultivated in different parts of the world in countries of tropical climates such as India, the Philippines, Malaysia, Senegal, Ethiopia and Mexico. HS is a semi-woody shrub plant that can reach up to $3 \mathrm{~m}$ high. It blooms annually or biennially, and its flowers consist of a purple red calyx and a corolla. ${ }^{11,12}$ Mexico is ranked as the seventh producer worldwide, with $5.14 \%$ of the total production, while China, ranked first, produces $27.76 \%$, followed by India with $17.91 \%$, Sudan $9.1 \%$, Uganda $8.40 \%$, Indonesia $6.23 \%$ and Malaysia $5.53 \% .^{13}$
Table 1. Taxonomic classification of $H S$

\begin{tabular}{cc}
\hline Kingdom & Plantae \\
\hline Subkingdom & Tracheobionta \\
\hline Division & Anthophyta \\
\hline Class & Magnoliopsida \\
\hline Order & Malvales \\
\hline Family & Malvaceae \\
\hline Genus & Hibiscus \\
\hline Species & sabdariffa L. \\
\hline
\end{tabular}

Source: Cid-Ortega and Guerrero-Beltrán, $2012^{11}$

\section{COMMON USES OF HS}

Fresh or dried calyces of HS are used in the preparation of beverages based on herbs, hot and cold drinks, fermented beverages, wine, jams, jellies, ice cream, chocolate, puddings, and cakes. ${ }^{14}$

In Egypt, the fleshy calyces are used in the manufacture of tea and fermented beverages ${ }^{14}$, while in Sudan and Nigeria, the calyces are boiled with sugar, to produce a known drink as "karkade" or "zoborodo". ${ }^{15,16}$

In Mexico, this beverage is called jamaica, agua de Jamaica [Hibiscus water] or té de Jamaica [Hibiscus tea]. In India, calyces are also used as colorants, flavorings and ingredients in rum. The seeds are eaten toasted or ground, while leaves and shoots are eaten raw or cooked, or as vegetables, known for its sour taste. ${ }^{14,16}$

In Sudan, the leaves are consumed green or dried, cooked with onions and peanuts, while in Malaysia the cooked leaves are eaten as vegetables. In Africa, the seeds are toasted or ground into powder and used in foods, such as soups and oily sauces, another use of the seed is as a coffee substitute. ${ }^{14-18}$

\section{MEDICINAL USES OF HS}

HS has also been widely used in traditional medicine. In India, Africa and Mexico, leaves or calyxes infusions are traditionally used for its diuretic, choleretic, febrifuges and antihypertensive effects, besides stimulating

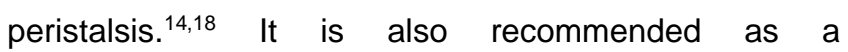
antihypertensive in Senegal. ${ }^{8}$ In Egypt, calyces have been used to treat heart and nervous system diseases and as 
a diuretic ${ }^{18}$. In Egypt and Sudan a calyces infusion (karkade), is also used to help reducing body temperature. ${ }^{14}$

In Guatemala it is used to treat drunkenness. ${ }^{18}$ In North Africa, calyces preparations are used to treat sore throats and cough, as well as genital infections; leaf pulp is used for external wounds and abscesses. ${ }^{19}$ In India, decoction seeds are used to relieve pain in urination and indigestion. $^{20}$ In Brazil, it is believed that roots have stomach and emollient properties ${ }^{18}$. Traditional Chinese medicine uses it for liver disorders and treat high $\mathrm{BP}^{18}$. In Iran, tea is a traditional treatment for $\mathrm{SAH}^{21}$, while in Nigeria, seeds' decoction is traditionally used to enhance or induce lactation in cases of low milk production. ${ }^{16}$

\section{NUTRITIONAL VALUE}

The nutritional composition of HS varies, due to genetic and environmental changes as well as specific characteristics of the cultivation and harvesting of the plant. Table 2 shows the average nutritional content of calyces. $^{22,23}$

Table 2. Nutritional content of fresh HS calyces

\begin{tabular}{ll}
\hline Content & Fresh calyces Amount per $\mathbf{1 0 0 \mathrm { g }}$ \\
\hline Protein & $1.9 \mathrm{~g}$ \\
\hline Fat & $0.1 \mathrm{~g}$ \\
\hline Carbohydrates & $12.3 \mathrm{~g}$ \\
\hline Fiber & $2.3 \mathrm{~g}$ \\
\hline Vitamin C & $14 \mathrm{mg}$ \\
\hline$\beta$ - Carotene & $300 \mu \mathrm{g}$ \\
\hline Calcium & $1.72 \mathrm{mg}$ \\
\hline Iron & $57 \mathrm{mg}$ \\
\hline
\end{tabular}

Source : Padmaja, et al., 2014 ${ }^{18}$ Carvajal-Zarrabal et al., $2012 .{ }^{24}$

\section{HS BIOACTIVE COMPOUNDS}

The main phytochemical constituents of HS, relevant for their pharmacological properties include organic acids, anthocyanins, polysaccharides and flavonoids. Phytochemicals or secondary metabolites refer to nonnutritious bioactive compounds, which are found naturally in almost all parts of the plant, such as flowers, leaves, stems, roots, bark, and seeds. These phytochemicals have antioxidant activity and seem to protect against various degenerative diseases and pathological processes. ${ }^{13-15,24-29}$

Calyces contain anthocyanins in 1.5\% (delphinidin-3 sambubioside or hibiscina, cyanidin-3-sambubioside, cyanidin-3-monoglucoside,delphinidin-3-monoglucoside), organic acids by $15 \%$ to $30 \%$, which stabilize the anthocyanins (mainly citric, malic, protocatechuic, tartaric and ascorbic acids), $50 \%$ of them corresponds to mucilaginous polysaccharides (uronic acids in form of salt and the rest rhamnose, arabinose, and small amounts of glucose, xylose and mannose), flavonoids (primarily quercetin, gossip trina, gosipetina, hibiscitrina and its aglycon hibiscetina), saponins ( $\beta$-sitosterol- $\beta$ Dgalactopiranosido), phytosterols ( $\beta$-sitosterol, camposterol, ergosterol, stigmasterol), pectin, and fiber. $24,26,29,30$

Nowadays, investigations have been carried out about the potential use of HS in the pharmacological field, due to its benefits as an alternative medicine, demonstrating diuretic $^{31,} \quad$ antioxidant $^{32,33}$, antiatherosclerotic ${ }^{34}$, hypocholesterolemic ${ }^{35-37}$, antihypertensive properties (as described below), among others. All these benefits are attributed to compounds present in the plant.

\section{ANTIHYPERTENSIVE PROPERTIES}

\section{STUDIES IN ANIMALS}

HS extracts have been tested to determine its hypotensive effect. Chronic administration of an extract of dried petals (250 mg / kg / day) significantly decreased BP $(p<0.001)$ in a group of hypertensive rats, even at normal values, without finding significant difference with the BP of rats in the control group. ${ }^{38}$ Also, diuretic effect of different calyces of HS extracts was tested. Likewise, the administration of HS extract $(20 \mathrm{mg} / \mathrm{kg}$ ) demonstrated a diuretic effect higher than the hydrochlorothiazide and furosemide in rats. ${ }^{38}$ This effect was significantly $(p<0.05)$ higher $(9.25 \mathrm{~mL}$ ) even when compared to controls treated with hydrochlorothiazide $(8.94 \mathrm{~mL})$ and furosemide (4.8 $\mathrm{mL}$ ). The extract did not induce macromorphological or histopathological alterations. ${ }^{38}$ 
Joven et al. ${ }^{39}$ reported that the daily administration of HS extract $(60 \mathrm{mg} / \mathrm{kg})$ in rats during one week, significantly reduced $\mathrm{BP}$ at day 7 , and it was observed a decrease on the diastolic blood pressure (DBP) in $25 \%(22-23 \mathrm{~mm} \mathrm{Hg})$.

\section{STUDIES IN HUMANS}

In human patients with $\mathrm{SAH}$, researches have also been conducted demonstrating the antihypertensive properties of HS extracts. Herrera-Arellano et al. ${ }^{40}$ administered a standardized extract of dried HS calyces $(9.6 \mathrm{mg}$ of anthocyanins) to a control group, while the experimental group received $25 \mathrm{mg}$ of captopril. Systolic blood pressure (SBP), DBP and heart rate significantly decreased in both groups. ${ }^{40}$ It is important to mention that the HS extract was similar in effectiveness to captopril. In addition, patients treated with the HS extract showed a significant increase in urinary sodium excretion $(p<0.001)$, without substantially modifying other urinary electrolytes, including potassium. ${ }^{40}$

In the same way, the clinical effect of a standardized extract of HS calyxes (250 mg total anthocyanins) was evaluated in patients with $\mathrm{SAH}$, using $10 \mathrm{~g}$ of lisinopril as control. ${ }^{41}$ The HS extract induced a significant reduction of BP $(p<0.05)$, with an effectiveness of $65.12 \%$. Both treatments were safe; while there was $100 \%$ of tolerability in the experimental group, there was $98.81 \%$ in the control group. ${ }^{41}$

Mozaffari-Khosravi et al. ${ }^{21}$ investigated the effect of administering $\mathrm{HS}$ tea on blood pressure, compared to black tea, in patients with SAH and diabetes type II. Both groups drank $250 \mathrm{~mL}$ of the corresponding tea twice a day, morning and evening, between main courses for a month. The HS group showed statistically significant differences throughout the study, SBP decreased from $134 \pm 11.8 \mathrm{~mm} \mathrm{Hg}$ to $112.7 \pm 5.79(p<0.001)$ at the end of the study. Likewise, the pulse fell from $52 \pm 12.2$ to $34.5 \pm 9.3$ ( $p<0.001)$. In the black tea group, the mean SBP and pulse did not show significant differences.

Another study was conducted in patients with SAH in its early stages, in order to evaluate the consumption of HS tea $(1.25 \mathrm{~g})$ or a placebo, three times a day $(720 \mathrm{~mL} /$ day $)$, for six consecutive weeks, over the BP. At the end of the treatment, the HS tea significantly decreased SBP by $27.2 \pm 11.4 \mathrm{~mm} \mathrm{Hg}$ versus placebo $21.3 \pm 10.0 \mathrm{~mm} \mathrm{Hg}$ $(p=0.030)$. DBP was also lower, although this change did not differ from the placebo $(23.1 \pm 7.0 \mathrm{~mm} \mathrm{Hg}$ versus $20.5 \pm 7.5 \mathrm{~mm} \mathrm{Hg}$ respectively, $\mathrm{p}=0.160) .{ }^{19}$

Chukwu et al., ${ }^{20}$ divided their population in three groups, Group A: they received a placebo, prepared from blackcurrant, is doses equivalent in volume to $150 \mathrm{mg} / \mathrm{kg}$ of the HS extract, administered orally, once a day before breakfast, for four weeks. Group B: patients were given $10 \mathrm{mg}$ of lisinopril, by oral route, once a day for four weeks. Group C: patients took orally $150 \mathrm{mg} / \mathrm{kg}$ of HS infusion once a day, before breakfast during four weeks. It was observed that in the group $\mathrm{C}$, the $\mathrm{BP}$ was reduced to normal levels in $76 \%$ of the cases, while lisinopril reached $65 \%$. Compared to the placebo, HS significantly decreased the SBP in week $2(p<0,01)$, and in weeks 3 and $4(p<0.001)$, while lisinopril significantly decreased the levels of SBP only until last week $(p<0.001)$. The effects of lisinopril and HS on the DBP were significant $(p<0.001)$ in weeks 3 and four as opposed to the placebo. The HS produced a significant reduction in the mean BP as of week 2, whereas lisinopril did it as of week 3 . At the end of the study, lisinopril and HS significantly reduced BP by $30.1 \%$ and $32.1 \%$, respectively $(p<0.001)$, compared to the placebo. However, there was no difference between both active treatments $(p>0.05)$. In addition, there were no side effects in groups $A$ and $C .{ }^{20}$

\section{TOXICITY}

In general, HS extracts have demonstrated to be safe. The lethal dose $\left(L D_{50}\right)$ varies from 2000 to more than 5000 $\mathrm{mg} / \mathrm{kg} /$ day. ${ }^{27,42}$

Also, there is evidence of a possible liver damage after a chronic consumption of doses higher than 3000 $\mathrm{mg} / \mathrm{kg} /$ day ${ }^{43}$ Severe weight loss and diarrhea have been observed with a dose of $2000 \mathrm{mg} / \mathrm{kg} /$ day for 90 days in laboratory animals. ${ }^{44}$

\section{CONCLUSIONS}

The studies in animal models and in human patients with $\mathrm{SAH}$, demonstrated the potential use that can be given to $\mathrm{HS}$, and it can be recommended as treatment for the early 
stages of this disease. However, studies that evaluate the potential of the plant in more advanced stages are needed, because most cases of SAH are diagnosed thanks to characteristic symptoms, which occur when the disease has progressed. In Mexico, HS represents an option to treat SAH because it is traditionally consumed, which favors its acceptance by the population, at the same time, it is a product economically affordable and physically easy to get, which favors even more its therapeutic use, especially in environments where medicines or money are very limited.

\section{REFERENCES}

1. Organización Mundial de la Salud. Información general sobre la hipertensión en el mundo, Una enfermedad que mata en silencio, una crisis de salud pública mundial. [internet] Ginebra: WHO Document Production Services. 2013. [cited 2017 jul 9]. Available from: http://apps.who.int/iris/bitstream/10665/87679/1/WHO_DCO_ WHD_2013.2_spa.pdf.

2. Pan American Health Organization. Día Mundial de la Hipertensión. [internet] PAHO. 2016. [cited 2017 jul 10]. Available from: http://www.paho.org/hq/index.php?option=com_content\&view $=$ article $\& \mathrm{id}=12023 \% 3 \mathrm{~A} 1-$ may-2016-world-

hypertensionday\&catid $=7261 \% 3$ Aevents-

$1 \&$ Itemid=41080\&lang=es.

3. Instituto Nacional de Salud Pública. Encuesta Nacional de Salud y Nutrición de Medio Camino 2016 (ENSANUT MC 2016) Informe final de resultados. [internet]. Cuernavaca, México: Instituto Nacional de Salud Pública. 2016. [cited 2017 jul 15]. Available from: http://www.epidemiologia.salud.gob.mx/doctos/encuestas/resul tados/ENSANUT.pdf

4. Sesma-Vázquez S, Pérez-Rico R, Sosa-Manzano CL, GómezDantés O. Gastos catastróficos por motivos de salud en México: magnitud, distribución y determinantes. Salud Públ. Méx. 2015;47(1):37-46.

5. Arévalo M, López M, López D, Martínez F. Adherencia a la terapéutica farmacológica en pacientes con hipertensión arterial. Rev. Méd. HJCA. 2016;8(1):8-13

6. Veliz-Rojasa L, Mendoza-Parrab, Barrigac OA. Adherencia terapéutica y control de los factores de riesgo cardiovasculares en usuarios de atención primaria. Enfer. Univ. 2015;12(1):3-11.

7. Chaupis-Meza D, Rojas J, Gasco M, Gonzales GF. Efecto hipotensor del extracto de ajo (Allium sativum) macerado por 18 semanas en un modelo experimental in vivo. Rev. Peru. Med. Exp. Salud Publica. 2014;31(3):461-466.

8. Dalí E. Nuevas aportaciones obre efectos del espino blanco (Crataegus sp) en patología cardiovascular. Rev. Fitoter. 2009;9(S1):69-74.

9. Rojas J, Ronceros S, Palomino R, Salas M, Azañero R, Cruz H, et al. Efecto coadyuvante del extracto liofilizado de Passiflora edulis (maracuyá) en la reducción de la presión arterial en pacientes tratados con enalapril. An. Fac. med. 2009;70(2):103108.

10. López M. Las plantas medicinales en el tratamiento de la HTA. Offarm. 2001; 20:112-117.

11. Cid-Ortega S, Guerrero-Beltrán JA. Propiedades funcionales de la Jamaica (Hibiscus sabdariffa L.). TSIA. 2012;6(2):47-63.

12. Salazar-González C, Vergara-Balderas FT, Ortega-Regules AE, Guerrero-Beltrán, JA. Antioxidant properties and color of Hibiscus sabdariffa extracts. Cien. Inv. Agr. 2012;39(1):79-90.

13. SAGARPA-Tecnológico de Monterrey. Plan rector nacional sistema producto jamaica. Comité nacional sistema producto jamaica. [internet]. SAGARPA. 2012. [cited 2017 jul 20]. Available from: http://dev.pue.itesm.mx/sagarpa/nacionales/EXP_CNSP_JAM AICA/PLAN\%20RECTOR\%20QUE\%20CONTIENE\%20PR OGRAMA\%20DE\%20TRABAJO\%202012/PR_CNSP_JAM AICA_\%202012.pdf.

14. Guardiola S, Mach N. Potencial terapéutico del Hibiscus sabdariffa: una revisión de las evidencias científicas. Rev. Endocrinol. Nutr. 2014;61(5):274-295.

15. Da-Costa-Rocha I, Bonnlaender B, Sievers H, Pischel I, Heinrich M. Hibiscus sabdariffa L. A phytochemical and pharmacological review. Food. Chem. 2014; 165:424-443.

16. Odigie IP, Ettarh RR, Adigun SA. Chronic administration of aqueous extract of Hibiscus sabdariffa attenuates hypertension and reverses cardiac hypertrophy in $2 \mathrm{~K}-1 \mathrm{C}$ hypertensive rats. $\mathrm{J}$. Ethnopharmacol. 2003; 86: 181-185.

17. Ramírez-Cortés B, Caro-Velarde F, Valdivia-Reynoso MG, Ramírez-Lozano MH, Machuca-Sánchez ML. Cambios en tamaño y características químicas de cálices de jamaica (Hibiscus sabdariffa L.) durante su maduración. Rev. Chapingo Ser. Hortic. 2011;8(2):19-31.

18. Padmaja H, Sruthi S, Vangalapati M. Review on Hibiscus sabdariffa a valuable herb. Int. J. Pharm. Life Sci. 2014;5(8):3747-3752.

19. McKay DL, Oliver Chen CY, Saltzman E, Blumberg JB. Hibiscus Sabdariffa L. tea (tisane) lowers blood pressure in prehypertensive and mildly hypertensive adults. J. Nutr. Desease. 2009; 140:298-303.

20. Chukwu ND, Ikemefuna AE, Fidelis OL, Zuada NN. Effects of aqueous extract of Hibiscus sabdariffa on the reninangiotensinaldosterone system of Nigerians with mild to moderate essential 
hypertension: A comparative study with lisinopril. Indian J. Pharmacol. 2015;47(5):540-545.

21. Mozaffari-Khosravi H, Jalali-Khanabadi BA, AfkhamiArdekani M, Fatehi F, Noori-Shadkam M. The effects of sour tea (Hibiscus sabdariffa) on hypertension in patients with type II diabetes. J. Hum. Hypertens. 2009; 23:48-54.

22. Sumaya-Martínez M, Medina-Carrillo RE, Machuca-Sánchez M, Jiménez-Ruiz E, Balois-Morales R, Sánchez-Herrera LM. Potencial de la jamaica (Hibiscus sabdariffa L.) en la elaboración de alimentos funcionales con actividad antioxidante. Rev. Mex. Agr. 2014;35(18):1082-1807.

23. Lin HH, Chen JH, Wang CJ. Chemopreventive properties and molecular mechanisms of the bioactive compounds in Hibiscus sabdariffa Linne. Curr. Med. Chem. 2011;18(8):1245-1254.

24. Carvajal-Zarrabal O, Barradas-Dermitz DM, Orta-Flores Z, Hayward-Jones PM, Nolasco-Hipólito C, Aguilar-Uscanga G, et al. Hibiscus sabdariffa L., roselle calyx, from ethnobotany to pharmacology. J. Pharmacol. Exp. 2012; 4:25-39.

25. Guzmán-Ortiz FA, Román-Gutiérrez AD, Castro-Rosas J, Gómez-Aldapa CA, Falfán-Cortés RN, Rodríguez-Marín ML. Compuestos bioactivos como una alternativa viable para disminuir la incidencia de enfermedades crónicas no transmisibles. In: Díaz Batalla L, Gómez-Aldapa CA, CastroRojas J, Téllez Jurado A, editors. Biotecnología y alimentos en Hidalgo: transitando a la bioeconomía. 1st ed. México: Amalgama Arte Editorial S.A. de C.V.; 2016:1-305.

26. Herranz-López M, Olivares-Vicente M, Encinar JA, BarrajónCatalán E, Segura-Carretero A, Joven J, et al. Multi-targeted molecular effects of Hibiscus sabdariffa polyphenols: an opportunity for a global approach to obesity. Nutrients. 2017;9(907):1-26

27. Hopkins AL, Lamm MG, Funk J, Ritenbaugh C. Hibiscus sabdariffa $\mathrm{L}$. in the treatment of hypertension and hyperlipidemia: a comprehensive review of animal and human studies. Fitoterapia. 2013; 85:84-94.

28. Ojedaa D, Jiménez-Ferrer, E, Zamilpa A, Herrera-Arellano A, Tortoriello J, Álvarez L. Inhibition of angiotensin convertin enzyme (ACE) activity by the anthocyanins delphinidin- and cyanidin-3-O-sambubiosides from Hibiscus sabdariffa. J. Ethnopharmacol. 2010; 127:7-10.

29. Serban C, Sahebkar A, Ursoniu S, Andrica F, Banach M. Effect of sour tea (Hibiscus sabdariffa L.) on arterial hypertension: a systematic review and meta-analysis of randomized controlled trials. J. Hypertens. 2015;33(6):1119-1127.

30. Castañeda R, Cáceres A. Compuestos bioactivos y propiedades terapéuticas de los cálices de rosa de jamaica (Hibiscus sabdariffa Linn). Rev. Cien. 2014;24(1):7-24.

31. Alarcon-Aguilar FJ, Zamilpa A, Perez-Garcia MD, AlmanzaPerez JC, Romero-Nunez E, Campos-Sepulveda EA, et al.
Effectof Hibiscus sabdariffa on obesity in MSG mice. J. Ethnopharmacol. 2007; 114:66-71.

32. Frank T, Netzel G, Kammerer DR, Carle R, Kler A, Riesl E, et al. Consumption of Hibiscus sabdariffa L. aqueous extract and its impact on systemic antioxidant potential in healthy subjects. J. Sci. Food. Agric. 2012; 92:2207-2218.

33. Ali BH, Mousa HM, El-Mougy S. The effect of a water extract and anthocyanins of Hibiscus sabdariffa $\mathrm{L}$ on paracetamolinduced hepatoxicity in rats. Phytother. Res. 2003; 17:56-59.

34. Chen CC, Hsu JD, Wang SF, Chiang HC, Yang MY, Kao ES, et al. Hibiscus sabdariffa extract inhibits the development of atherosclerosis in cholesterol-fed rabbits. J Agric Food Chem. 2003; 51:5472-5477.

35. Carvajal-Zarrabal O, Waliszewski SM, Barradas-Dermitz DMA, Orta-Flores Z, Hayward-Jones PM, Nolasco-Hipolito C, et al. The consumption of Hibiscus sabdariffa dried calyx ethanolic extract reduced lipid profile in rats. Plant Food Hum. Nutr. 2005; 60:153-159.

36. Gurrola-Diaz CM, Garcia-Lopez PM, Sanchez-Enriquez S, Troyo-Sanroman R, Andrade-Gonzalez I, Gomez-Leyva JF. Effects of Hibiscus sabdariffa extract powder and preventive treatment (diet) on the lipid profiles of patients with metabolic syndrome (MeSy). Phytomed. 2010; 17:500-505.

37. Mohagheghi A, Maghsoud S, Khashayar P, Ghazi-Khansari. The effect of Hibiscus sabdariffa on lipid profile, creatinine, and serum electrolytes: a randomized clinical trial. ISRN Gastroenterol. 2011; 2011:976019.

38. Márquez VR, De La Rosa TC, Rivero CA, Medina MM. Actividad diurética del extracto total acuoso de los cálices de Hibiscus sabdariffa L. administrado en ratas albinas variedad Wistar. Sci. Tech. Año XIII. 2007; 33:377-381.

39. Joven J, March I, Espinel E, Fernández-Arroyo S, RodríguezGallego E, Aragonés G, et. al. Hibiscus sabdariffa extract lowers blood pressure and improves endothelial function. Mol. Nutr. Food Res. 2014;58:1374-1378.

40. Herrera-Arellano A, Flores-Romero S, Chávez-Soto MA, Tortoriello J. Effectiveness and tolerability of a standardized extract from Hibiscus sabdariffa in patients with mild to moderate hypertension: a controlled and randomized clinical trial. Phytomedicine. 2004;11:375-382.

41. Herrera-Arellano A, Miranda-Sánchez J, Ávila-Castro $P$, Herrera-Álvarez S, Jiménez-Ferrer JE, Zamilpa A, et al. Clinical effects produced by a standardized herbal medicinal product of Hibiscus sabdariffa on patients with hypertension. A randomized, double-blind, Lisinopril-Controlled clinical trial. Planta med. 2007;73:6-12.

42. Ndu OO, Nworu CS, Ehiemere CO, Ndukwe NC, Ochiogu IS. Herb-drug interaction between the extract of Hibiscus sabdariffa 
L. and hydrochlorothiazide in experimental animals. J. Med. Food. 2011; 14:640-644.

43. Akindahunsi AA, Olaleye, MT. Toxicological investigation of aqueous-methanolic extract of the calyces of Hibiscus sabdariffa L. J. Ethnopharmacol. 2003; 89:161-164.

44. Fakeye TO, Pal A, Bawankule DU, Yadav NP, Khanuja SP. Toxic effects of oral administration of extracts of dried calyx of Hibiscus sabdariffa Linn. (Malvaceae). Phytother. Res. 2009; 23:412-416 